\title{
V. Description of a horse without hair
}

\section{De Lasteyrie}

To cite this article: C. De Lasteyrie (1801) V. Description of a horse without hair, Philosophical Magazine Series 1, 10:37, 36-38, DOI: 10.1080/14786440108675885

To link to this article: http://dx.doi.org/10.1080/14786440108675885

$$
\text { 册 Published online: } 18 \text { May } 2009 .
$$

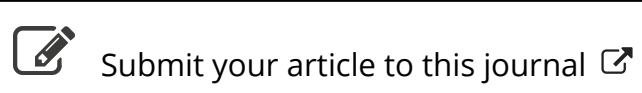

\footnotetext{
Џll Article views: 2
}

Q View related articles $\asymp$ 
trace, which undulated at the furface of the falt. But this effect is doubtful : when projected on iguited iron, it retained a light fcarcely fenfible.

In the laft place, I fubjected to diftillation, at a red heat, in a luted glafs retort, one gramme and, a half ( 23.16 grains) of this fubitance. I obtained fome drops of a liquid tranfparent as water, and a quantity of air which did not exceed the capacity of the veffels ufed for diftilling. This air contained one or two hundredths of carbotic acid gas ; a quantity inferior to what I expected to obtain by the decompofition of water and the inflammable matter contained in the clay. The carbonic acid gas, naturally belonging to the air of the veffels anterior to the diftillation, muft be deducted from the eftimation I have given.

XII. I thall recapitulate, in a few words, the principal refults of thefe obfervations:

Ift, Alumine does not form with carbonic acid a concrete carbonate of alumine; or, at leaft, no one has been able to form that combination.

2d, The fubltance, hitherto confidered as artificial concrete carbonate of alumine, is the refult of the union of alumine with alkali and carbonic acid. This acid does not, probably, enter into this combination but by its affinity for the alkali.

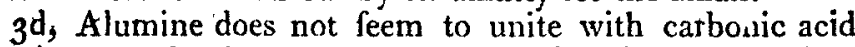
but in the cafe when the latter is diffolved in water; when this earth precipitates itfelf from this folution by the volatilization of the carbonic acid, it does not appear in the fate of carbonate.

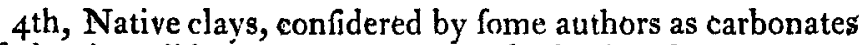
of alumine, did not appear to me to be in that ftate.

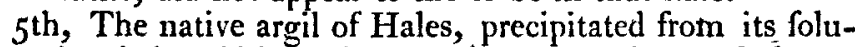
tions in nitric acid by carbonate of ammonia in excefs, leaves in folution in the latter falt, a fubftance or combination which deferves further examination.

[To be continued.]

V. Defcription of a Horfe witbout Hair. By C. DE Lasteyrie, Member of the Pbilomatic Society*.

$\mathrm{T}$ wonders which it continually prefented to their minds fell into the marvellous, becaufe they were as yet unacquainted with its laws, its means, and its powers. Such is the origin

* From the Fournal de Pby/fque, Floreal, an. 9. 
of thofe ridiculous tales and abfurd fuppofitions to be found in antient authors, and which have been tranfmitted, from age to age, till the period when mankind began to examine with more accuracy, and to make better obfervations.

By multiplying refearches they have been rendered more exact: at prefent there is no neceffity for believing a fact merely becaufe it contains fomething of the marvellous, or is mentioned by fuch or fuch an author.

Is the horfe without hair, which forms the fubject of this article, to be confidered as a new varietv in the fpecies, or are the characters by which this feems to be indicated a mere accident, produced by difeafe, or the effect of art? The proofs I have obtained, and the obfervations I have made on this animal, incline me to believe that it is an individual of a peculiar variety. "Inftead of contracting the limits of its power," fays Buffon, fpeaking of nature, "we mult enlarge and extend them eveu to immenfity; we muft fee nothing impoffible, we muft fuppofe every thing, and believe that every thing which can be really exifts!" Though the number, indeed, of the travellers who give themfelves the trouble to make obfervations is very inconfiderable, we however are daily made acquainted with new facts, and we fee nature extended in proportion as we give extenfion to our refearches. By comparing the countries, the productions of which are known with thofe which have not yet been examined by naturalifts, it may be eufily perceived that the field which remains for us to be paffed over is of greater extent than that paffed over by our predeceffors. If the number of the fubftances contained in the bowels of the earth, and that of the beings which elude our refearches at its furface, is prodigious, may we not alfo believe that there exift fubftances and beings more eafily to be difcovered, of which, however, we have as yet no accounts?

I thall now relate the hiftory of the horfe without hair and mane, fuch as I received it.-He was purchafed, about ten years ago, at Vienna, by a Frenchman named Alpi, formerly employed in the menagerie of Verfailles, by whom he was exhibited in feveral towns of Germany with other animads, and afterwards fold, for fifty louis, to the Veterinary School at Berlin. This horfe had been taken from the Turks during the laft war, and carried by an Autrian officer to Vienna. Alpi exhibited him under the name of the Horfe of the Nile, and faid he came from Africa. He yoked him to a cart on which he carried about his animals. Four years ago be was in the Veterinary College of Berlin.

This horfe appears to me to be about twenty years of age; $\mathrm{C}_{3}$ 
he eats the fame food, and in the fame quantity, as common horfes : he is meagre, as he always had been from the time he was brought to the Veterinary School. He is ftrong and vigorous, trots fomewhat hard on account of his age, and becaufe he has been employed in the draught. He is very fenfible to cold, and therefore during winter is always kept exceedingly warm. His head is fmall and well made, the neck pretty, and the cheft open; his legs, on which he ftands well, are flender; but the reft of his body is not fo beautiful, on account of his age and meagre ftate.

He differs from other horfes only in the want of hair, the depreffion of his forehead, and the noife he makes when breathing. I have carefully obferved all the parts of his body, even the interior of the ears, and I bave found only a black brittle, about three-tenths of an inch in length, on the lower eye-lid of the left eye. His kin is of a black colour inclining to gray, with fome white fpots on the flanks and groin. It is plaited on the upper part of the cheft, is very foft to the touch on the whole body, and has a Mining and unctuous appearance. What gives reafon to believe that the want of hair in this animal is neither the effect of art nor the refult of difeafe is, that the fkin on the nofe, around the noftrils, and on the upper and lower lips, differs from that of other horfes, and has all the characters above indicated : it has almoft all the appearances of that of the Turkinh dog. A very difinguifhing character is the depreffion in the middle of the forehead, meafuring from the anterior angle of the eyes and the angle of the mouth. This depreffion, which contracts the aperture formed by the nafal bone, occafions fome embarraffment to the animal in breathing, and at each infpiration and expiration it makes a noife which may be compared to that made by a perfon when the noftrils are obftructed. This-noife increafes when the animal has been running, or employed in hard labour. He has, hawever, ftrong lungs and good wind.

VI. Defoription of a xequly incented Galvanometer, and an Account of forme Experixuents made quitb Volta's Pile upon frueral of the Gafes. By W. H. PEPYs jun, $E / q$ :*

D

URING a courfe of experiments upon atmolpheric electricity, with which I occupied myfelf in the year 1798, I

* Communicated by the autlor. 